\title{
Carbon nanotubes functionalized by salts containing stereogenic heteroatoms as electrodes in their battery cells
}

\author{
Sandra Zdanowska, Magdalena Pyzalska, Józef Drabowicz, Damian Kulawik, Volodymyr Pavlyuk, \\ Tomasz Girek, Wojciech Ciesielski*
}

Jan Dlugosz University in Czestochowa, Institute of Chemistry, Environmental Protection and Biotechnology, Armii Krajowej 13/15, 42-201 Czestochowa, Poland

"Corresponding author: e-mail: wc@ajd.czest.pl

\begin{abstract}
This paper concentrates on electrochemical properties of groups of multi-walled carbon nanotubes (MWCNT) functionalized with substituents containing a stereogenic heteroatom bonded covalently to the surface of the carbon nanotube. This system was tested in Swagelok-type cells. The cells comprised a system (functionalized CNT with salts containing $\mathrm{S}$ and $\mathrm{P}$ atoms) with a working electrode, microfiber separators soaked with electrolyte solution, and a lithium foil counter/reference (commercial $\mathrm{LiCoO}_{2}$ ) electrode. The electrolyte solution was $1 \mathrm{M} \mathrm{LiPF}_{6}$ in propylene carbonate. Using standard techniques (cyclic voltammetry/chronopotentiometry), galvanostatic cycling was performed on the cells at room temperature with a $\mathrm{CH}$ Instruments Model 600E potentiostat/galvanostat electrochemical measurements. Methods of functionalization CNT were compared in terms of the electrochemical properties of the studied systems. In all systems, the process of charge/discharge was observed.
\end{abstract}

Keywords: multi-walled carbon nanotubes (MWCNT), battery, bromination, charge transfer, X-ray spectroscopy, electronic structure.

\section{INTRODUCTION}

Lithiated transition metal oxides are of great interest for fundamental studies and practical applications such as positive electrode materials for rechargeable lithium-ion batteries ${ }^{1-3}$. In comparison to commonly used $\mathrm{LiCoO}_{2}$ electrodes, $\mathrm{LiNiO}_{2}$ is cheaper and has a higher energy density ( $20 \%$ higher by weight), but is less stable ${ }^{3,4}$. The phase relationship between $\mathrm{NiO}$ (NaCl-type), $\mathrm{LixNi}_{1}-{ }_{\mathrm{x}} \mathrm{O}$ (disordered $\mathrm{NaCl}), \mathrm{Li}_{1}-\mathrm{NiO}_{2}$, and $\mathrm{LiNiO}_{2}\left(\alpha-\mathrm{NaFeO}_{2}-\right.$ type) was described by Kanno et al. ${ }^{5}$. $\mathrm{LiNiO}_{2}$ is isostructural to $\mathrm{LiCoO}_{2}$ and has a layered structure of $\alpha-\mathrm{NaFeO}_{2}-$ type (R-3m space group). At higher temperatures, $\mathrm{LiNiO}_{2}$ decomposes to disordered rhombohedral $\mathrm{Li}_{1}-{ }_{\mathrm{X}} \mathrm{NiO}_{2}$ and cubic $\mathrm{Li}_{\mathrm{X}} \mathrm{Ni}_{1}-\mathrm{X}_{\mathrm{x}} \mathrm{O}$ phases. At the intermediate composition of $\mathrm{Li}_{0.63} \mathrm{Ni}_{1.02} \mathrm{O}_{2}$, the formation of the monoclinic phase $\left(\mathrm{C}_{2} / \mathrm{m}\right.$ space group) was observed and previously studied by Pérès et al. ${ }^{6}$. In recent years, $\mathrm{Li}(\mathrm{Ni}, \mathrm{Co}) \mathrm{O}_{2}$ or $\mathrm{Li}(\mathrm{Ni}, \mathrm{Mn}, \mathrm{Co}) \mathrm{O}_{2}$ compositions containing different or equal amounts of the transition metals as have been the most commonly used cathode materials, for example, $\mathrm{LiNi}_{1}-{ }_{\mathrm{x}} \mathrm{Co}_{\mathrm{x}} \mathrm{O}_{2}(\mathrm{x} \sim 0.8)^{7-9}$ and $\mathrm{Li}\left(\mathrm{Ni}_{1 / 3} \mathrm{Mn}_{1 / 3} \mathrm{Co}_{1 / 3}\right) \mathrm{O}_{2}{ }^{10,11}$ have been used to prepare low-cost and high-capacity electrodes. The process of $\mathrm{Li}$ insertion into chromium oxides by both chemical and electrochemical methods was first presented by Koksbang and Norby ${ }^{12}$. Chromium oxides, especially $\mathrm{LiCr}_{3} \mathrm{O}_{8}$, are attractive as constituents for cathode materials because they have high capacity at low discharge rates ${ }^{13}$. In the industrialized world, the development of energy resources (e.g., oil, natural gas) has become essential for agriculture, transportation, waste collection, information technology, and communications that have become prerequisites of a developed society. The forecasts for energy needs make it necessary to look for new alternative sources of energy for environmentally friendly batteries. Currently, a very promising solution is to store energy using cells composed of ternary systems such as alloys and composites. We have developed lightweight alloys and intermetallic compounds. Lithium alloys (Li-Me-O) can be used as electrodes in batteries.
Based on an analogy with the procedure for the attachment of oxygen and nitrogen radicals to salt of single-walled carbon nanotubes synthesis is based on the use of feedstock carbon nanotubes (MWCNT and SWCNT $)^{14}$. Carbon nanotubes are functionalized on the outer surfaces of the reactive functional groups $[\mathrm{C}(\mathrm{O})$ $\left.\mathrm{Cl}, \mathrm{OH}, \mathrm{NH}_{2}\right]^{15}$, and functionalization process based on ionic character of carbon atoms in carbon nanotubes ${ }^{16-18}$. The proposed methodology utilizes, inter alia, the nature of the electrophilic carbon atoms in the halogenated carbon nanotubes allowing a nucleophilic substitution reaction ${ }^{19,20}$. In this case, the „covalent” functionalization of carbon nanotubes is planned by reacting halogenated carbon nanotubes, CNT(X)4, with several anions containing heteroatoms. These reactions should lead to modified CNT carbon nanotubes with the general structure $\left(\mathrm{R}^{*}\right) 4$. The joining of heteroatoms containing salt to native carbon tubes is based on the reaction of carbanions generated by the addition to them of the salts with oxidizing solvents ${ }^{21}$. This will lead to the creation of derivatives of the native nanotubes with a direct carbon-heteroatom bond [structured CNT $=(\mathrm{R})(\mathrm{Z})$, where $\mathrm{R}=$ alkyl and $\mathrm{Z}=\mathrm{R} 1 \mathrm{~S}(\mathrm{O})$ or R1 R2 P (O) $]^{22}$.

Based on the literature and study results described in the previous paper ${ }^{23}$, we continued modifications of the multiwall carbon nanotubes (MWCNT) with thiophosphoorganic salts along with simultaneous evaluation of their effect on electronic properties of the MWCNT.

\section{MATERIAL AND METHODS}

\section{Halogenation of carbon nanotubes}

In order to increase the reactivity of the MWCNT, bromine atoms were introduced into the structure of native carbon nanotubes ${ }^{24-26}$. Halogenation of carbon nanotubes was carried out according to the procedure described in the patent ${ }^{27}$. 


\section{Functionalization of halogenated carbon nanotubes}

Syntheses of MWCNT containing a covalently bonded substituent based on nucleophilic substitution reactions of halogenated carbon nanotubes with anions containing a stereogenic heteroatom. Sulfenylation and phosphonylation of carboanionic derivatives of carbon structures generated by the additions of alkyllithiums to native carbon nanotubes ${ }^{21}$.

The first system of the modified MWCNT was obtained according to the process ${ }^{23}$. For the synthesis of the second system, diethyl dithiophosphoric acid sodium salt (Scheme 1) was used. Brominated MWCNT with $\mathrm{S}-\mathrm{P}\left(\mathrm{S}^{-}\right)(\mathrm{OEt})_{2} \mathrm{Na}^{+}$was introduced to a round-bottom flask,maintaining a mass ratio of 1: 3 in THF and mixing the content for three days. The reaction proceeded according to scheme 1 . The raw product was subjected to a three-stage purification according to the procedure described in Ref. ${ }^{23}$.

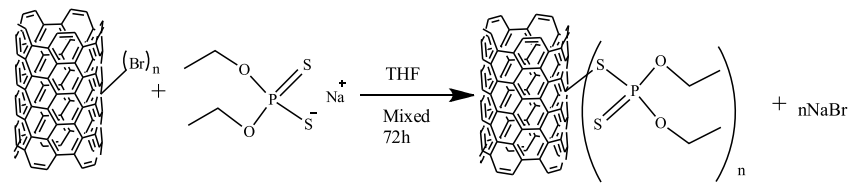

Scheme 1. Reaction of brominated MWCNT with S-P(S-)(OET) $\mathrm{Na}+$

\section{Scanning electron microscopy}

Morphology of the brominated and functionalized surfaces of MWCNT was assessed using Tescan Vega 3 SBU scanning electron microscope (Tescan, Brno, Czech Republic) with EDS analyzer.

\section{Fourier transform infrared spectroscopy (FTIR)}

FTIR spectra were performed in $\mathrm{KBr}$ pellets using FTIR Nexus Nicolet spectrophotometer (Madison, WIS., USA) within the range of $4000-400 \mathrm{~cm}^{-1}$.

\section{Electrochemical investigations}

In model experiments, $10 \mathrm{mg}$ of the functionalized MWCNT were introduced into $0.1 \mathrm{~mL} 1 \mathrm{M} \mathrm{LiPF}_{6}$ solution in propylene carbonate. The content was ground in the agate mortar for $2 \mathrm{~min}$. The resulting paste was applied on the working electrode of the cell, and then tightly closed. The second electrode (cathode) was made analogously by grinding $\mathrm{LiCoO}_{2}$ alloy in the agate mortar for $2 \mathrm{~min}$ with $0.1 \mathrm{~mL} 1 \mathrm{M} \mathrm{LiPF}_{6}$ solution in propylene carbonate. The resulting paste was applied on the cathode of the cell and closed tightly. The third electrode was the reference electrode (metallic lithium). Experiments were performed at $25^{\circ} \mathrm{C}$.

\section{RESULTS AND DISCUSSION}

Considering the capability of producing carbocation in brominated MWCNT, they were used as a starting material for further functionalization.

The brominated MWCNTs needed for the experiments were obtained according to our recently patented procedure based on direct bromination of the native nanotubes in the vapor of elemental bromine ${ }^{26}$. The presence of covalently bound bromine in the reaction product, which was purified several times to remove traces of non-covalently bound bromine, was confirmed by the analysis of the Energy Dispersive X-ray (EDS) spectrum that showed clear bromine peaks $(\mathrm{Br} 3 \mathrm{~s}$ and $3 p$ peaks) $[3.0 \%$ by weight of bromine in the sample] (Fig. 1). This analysis showed that the resulting product contained covalently bound bromine atoms (Fig. 1).

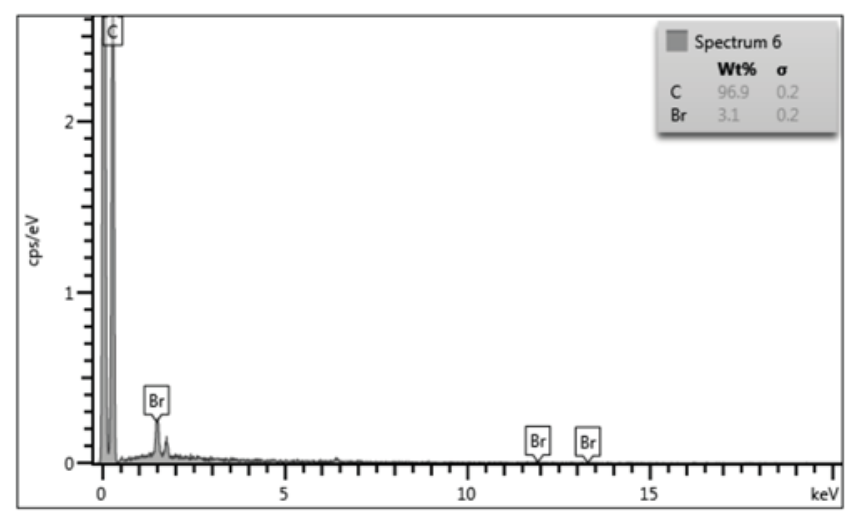

Figure 1. Energy Dispersive X-ray (EDS) spectrum of brominated MWCNTs after purification

\section{Functionalization of brominated MWCNT}

The EDS spectrum of modified MWCNT of tiophosphoroorganic salts (Figs. 2a and b) recorded for a sample of the reaction product in which traces of the non-covalently bound phosphorus-containing reagent were removed by multiple purification of the crude product. In the Figure both, bromine peaks and the $\mathrm{P}$ and $\mathrm{S}$ peaks are visible. Their presence clearly indicates that bromine was partially replaced by the phosphorus-containing residue. This result opens the way for further functionalization with the use of other chiral anions, and these studies are currently being pursued in our laboratory.
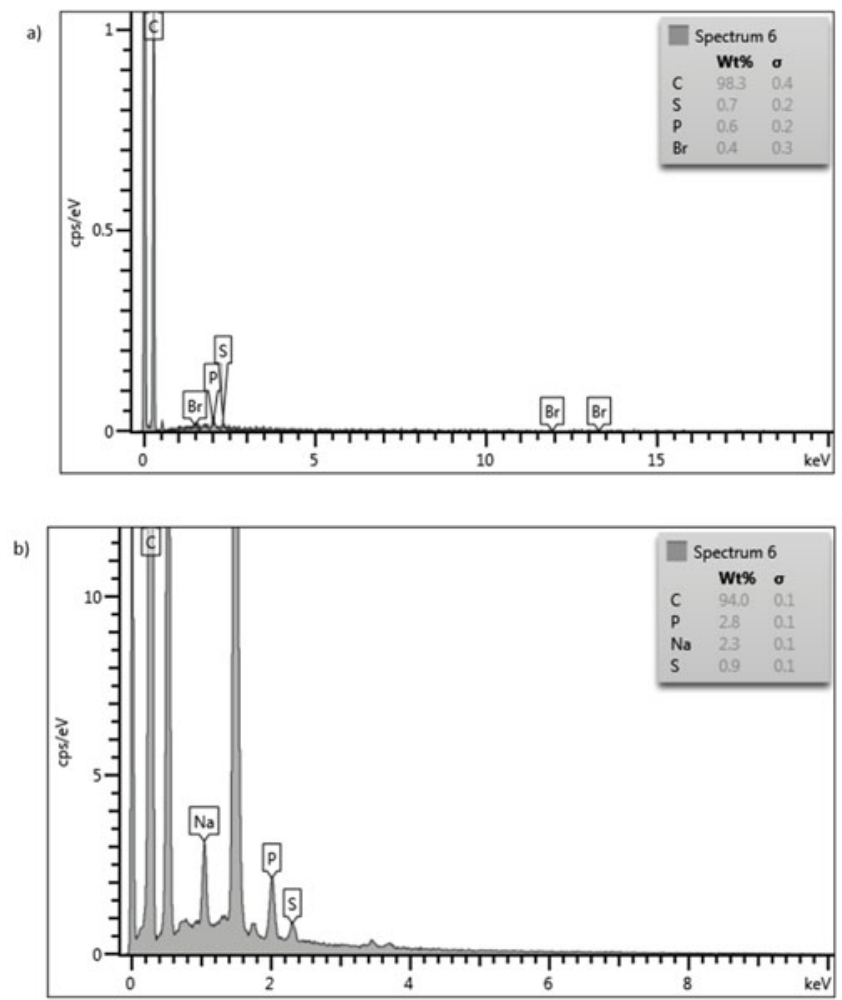

Figure 2. Energy Dispersive X-ray spectrum (EDS) of (a) MWCNT/S-P(O)OMeONph system [22] and (b) MWCNT/S-P(S)(OEt) $)_{2}$ system 


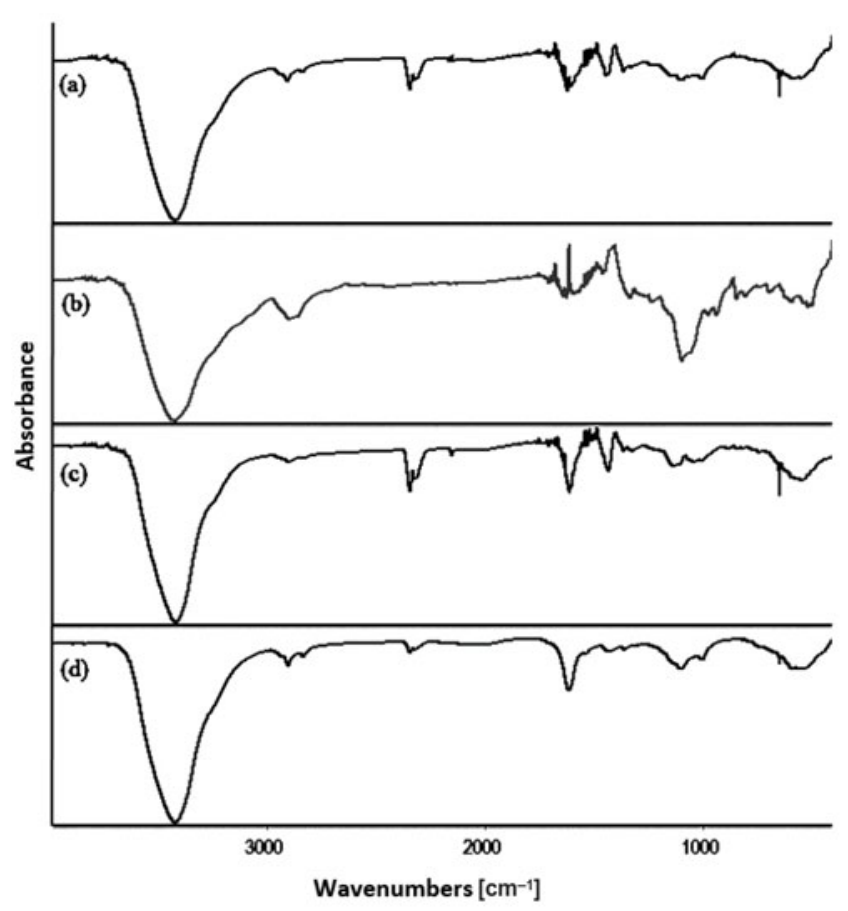

Figure 3. Fourier-transform infrared spectra of (a) native carbon nanotube, (b) Br-MWCNT system (c) MWCNT/S-P(O) $\mathrm{OMeONph}$ system, and (d) MWCNT/S-P(S)(OEt) $)_{2}$ system

FTIR analysis of native MWCNT is different compared to the FTIR spectra of commonly known aromatic compounds because native carbon nanotubes are characterized by a global symmetric structure causing a reduction of bands intensity for $\mathrm{C}-\mathrm{C}$ bonds. In Figure 3a, we do not observe intense bands for $\mathrm{C}=\mathrm{C}$ stretching vibrations (located at a wavelength of $1551 \mathrm{~cm}^{-1}$ ) while the broad band observed at a wavelength of about $3500 \mathrm{~cm}^{-1}$ is associated with potassium bromide water absorption.

Compared to native MWCNT, brominated carbon nanotubes (Fig. 3b) demonstrate vibrations in the finger print region that correspond to the vibrations stretching C-Br bonds $\left(615 \mathrm{~cm}^{-1}\right)$, while deformation vibrations at a wavelength of $1117 \mathrm{~cm}^{-1}$ are attributed to aryl-Br group vibrations.

FTIR measurement performed for phosphoorganic salt systems with carbon nanotubes (Figs. 3c and 3d) shows the reduction of intensity of the bands attributed to $\mathrm{C}-\mathrm{Br}$ bond vibrations. Simultaneously, we observe new bands at a wavelength of $1631 \mathrm{~cm}^{-1}$ (for MWCNT/S-P(O) OMeONph system) and $1632 \mathrm{~cm}^{-1}$ (for MWCNT/S-P(S) $(\mathrm{OEt})_{2}$ system) that correspond to the vibration of the conjugated $\mathrm{C}=\mathrm{C}$ bonds and the thioester group. Changes are also observed in the finger print region where vibrations for the $\mathrm{P}=\mathrm{S}$ group at a wavelength of 668 $\mathrm{cm}^{-1}$ (for MWCNT/S-P(O)OMeONph system) and 663 $\mathrm{cm}^{-1}$ (for MWCNT/S-P(S)(OEt) 2 system), are reported.

\section{ELECTROCHEMICAL STUDIES}

Electrochemical properties of the functionalized MWCNT were analyzed in the electrochemical measurement, in which $\mathrm{LiCoO}_{2}$ alloy served as a cathode. The electrochemical measurement performed for the MWCNT/S-P(O)OMeONph system (1) showed that the capacity between the first and the twentieth cycle was $190 \mathrm{mAh} / \mathrm{g}(\mathrm{n}=1)$ and $137 \mathrm{mAh} / \mathrm{g}(\mathrm{n}=25)$ - de- crease in capacity by $29 \%$. While the cell capacity, in which the MWCNT/S-P(S)(OEt) $)_{2}$ system (2) served as a working electrode (anode), was $207 \mathrm{mAh} / \mathrm{g}(\mathrm{n}=1)$ and $151 \mathrm{mAh} / \mathrm{g}(\mathrm{n}=25)$ - decrease in capacity by $27 \%$. This demonstrates the improved resistance of the cell (2) against charge/discharge processes.

Chronopotentiometric measurement for the system 1 demonstrated a stable operation of the cell within the range of 2.2-4.8 V (Fig. 4). While for system 2, stable operation of the cell was reported within the range of $-0.3-2.4 \mathrm{~V}$ (Fig. 4b), for system 2, splitting vertices that can indicate a potential energy accumulation in the cell, are observed. Both cells during charge/discharge cycles demonstrated stable operation without any significant loss of potential performance. After cyclic voltammetry measurement, it was demonstrated that in both systems, overlapping bands that do not indicate a potential loss of electrode performance, were observed (Figs. 5a and 5b).
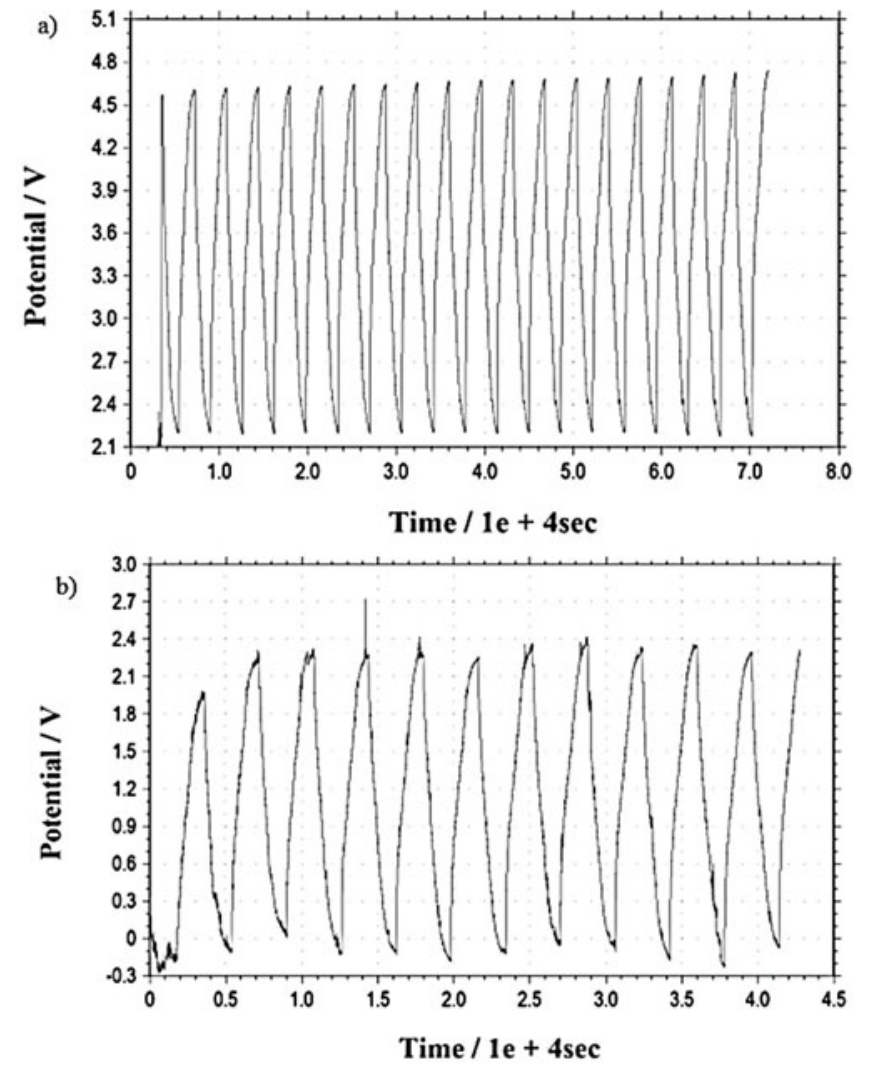

Figure 4. Chronopotentiometric measurement of (a) MWCNT/S$\mathrm{P}(\mathrm{O}) \mathrm{OMeONph}$ system and (b) MWCNT/S-P(S)(OEt) system

The discharge capacity of electrodes as a function of the number of cycles is shown in Figure 6. Obviously, this is due to the fact that in the MWCNT/S-P $(\mathrm{S})(\mathrm{OEt})_{2}$ system, the lithium atoms do not occupy separate crystallographic sites, but are only partially included in MWCNT sphere. The lithium layer is located between layers of functionalized MWCNT, thereby reducing the lithium diffusion coefficient and the power capability of the electrode.

The figures 4-6 shows the high level of stability of the battery and the high number of charge-discharge cycles without the loss of cell efficiency. Preliminary studies indicate that the life of the battery may be long. 
As time passes, we see an increase in power in the cell when charging and discharging (Fig. 6).
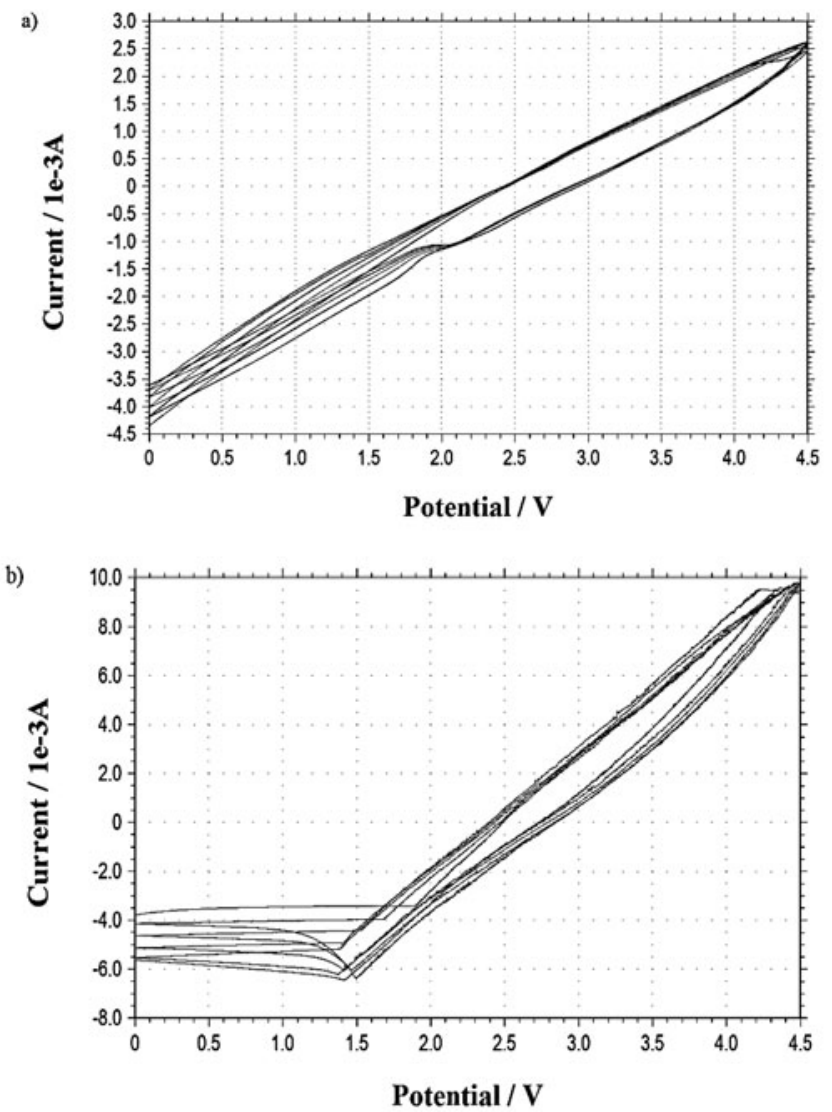

Figure 5. Cyclic voltammetry measurements of (a) MWCNT/S$\mathrm{P}(\mathrm{O}) \mathrm{OMeONph}$ system and (b) MWCNT/S-P(S)(OEt) system

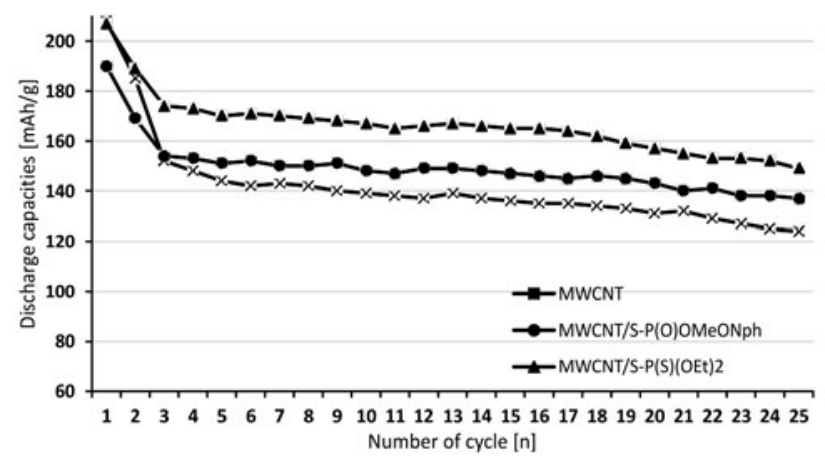

Figure 6. Discharge capacities vs. cycle number of MWCNT, MWCNT/S-P(O)OMeONph and MWCNT/S-P(S) $(\mathrm{OEt})_{2}$ systems

\section{CONCLUSIONS}

Modification methods of MWCNT used by our group provide the possibility to use functionalized MWCNT in devices powered by electricity. Introduction of phosphoorganic salts into the structure of MWCNT increases the stability of work with simultaneous increase in performance and life span of the cell. However, phosphoorganic salts with smaller cation provide broader opportunities in the commercialization of such systems, because there is no effect of excessive competition between cations in terms of charge transfer.

\section{ACKNOWLEDGEMENTS}

The studies presented here were in part financially supported (as grants for J.D.) by National Science Center award UMO-2015/19/N/ST8/03922.

\section{LITERATURA CITED}

1. Fergus, J.W. (2010). Recent developments in cathode materials for lithium ion batteries. J. Pow. Sou. 195, 939-954. DOI: 10.1016/j.jpowsour.2009.08.089.

2. Antolini, E. (2004). $\mathrm{LiCoO}_{2}$ : formation, structure, lithium and oxygen nonstoichiometry, electrochemical behaviour and transport properties. Sol. State Ionics. 170, 159-171. DOI: 10.1016/j.ssi.2004.04.003.

3. Rougier, A., Bravereau, P. \& Delmas, D. (1996). Optimization of the composition of the $\mathrm{Li}_{1-}{ }_{7} \mathrm{Ni}_{1}+{ }_{2} \mathrm{O}_{2}$ electrode materials: structural, magnetic, and electrochemical studies. J. Electrochem. Soc.143, 1168-1175. DOI: 10.1149/1.1836614.

4. Liu, H., Yang, Y. \& Zhang, J. (2007). Reaction mechanism and kinetics of lithium ion battery cathode material $\mathrm{LiNiO}_{2}$ with $\mathrm{CO}_{2}$. J. Pow. Sou. 173, 556-561. DOI: 10.1016/j.jpowsour.2007.04.083

5. Kanno, R., Kubo, H., Kawamoto, Y., Kamiyama, T., Izumi, F., Takeda, Y. \& Takano, M. (1994). Phase Relationship and Lithium Deintercalation in Lithium Nickel Oxides. Sol. State Chem. 110, 216-225. DOI: 10.1006/jssc.1994.1163.

6. Pérès, J.P., Demourgues, A. \& Delmas, C. (1998). Structural investigations on $\mathrm{Li}_{0.65}-{ }_{2} \mathrm{Ni}_{1}+{ }_{2} \mathrm{O}_{2}$ cathode material: $\mathrm{XRD}$ and EXAFS studies. Sol. State Ion. 111, 135-144. DOI: 10.1016/ S0167-2738(98)00122-2.

7. Li, D., Peng, Z., Ren, H., Guo, W. \& Zhou, Y. (2008). Synthesis and characterization of $\mathrm{LiNi}_{1}-{ }_{\mathrm{X}} \mathrm{Co}_{\mathrm{x}} \mathrm{O}_{2}$ for lithium batteries by a novel method. Mater. Chem. Phys. 107, 171-176. DOI: $10.1021 / \mathrm{cm} 0102537$.

8. Baskaran, R., Kuwata, N., Kamishima, O., Kawamura, J. \& Selvasekarapandian, S. (2009). Structural and electrochemical studies on thin film $\mathrm{LiNi}_{0.8} \mathrm{Co}_{0.2} \mathrm{O}_{2}$ by PLD for micro battery. Sol. State Ion. 180, 636-643. DOI: 10.1016/j.ssi.2008.11.012.

9. Sakamoto, K., Hirayama, M., Sonoyama N., Mori, D., Yamada, A., Tamura, K., Mizuki, J. \& Kanno, R. (2009). Surface Structure of $\mathrm{LiNi}_{0.8} \mathrm{Co}_{0.2} \mathrm{O}_{2}$ : a New Experimental Technique Using in Situ X-ray Diffraction and Two-Dimensional Epitaxial Film Electrodes. Chem. Mater. 21(13), 2632-2640. DOI: $10.1021 / \mathrm{cm} 8033559$.

10. Martha, S.K., Sclar, H., Framowitz, Z.S., Kovacheva, D., Saliyski, N., Gofer, Y., Sharon, P., Golik, E., Markovsky, B. \& Aurbach, D. (2009). A comparative study of electrodes comprising nanometric and submicron particles of $\mathrm{LiNi}$ ${ }_{0.50} \mathrm{Mn}_{0.50} \mathrm{O}_{2}, \mathrm{LiNi}_{0.33} \mathrm{Mn}_{0.33} \mathrm{Co}_{0.33} \mathrm{O}_{2}$, and $\mathrm{LiNi}_{0.40} \mathrm{Mn}_{0.40} \mathrm{Co}_{0.20} \mathrm{O}_{2}$ layered compounds. J. Pow. Sou. 189, 248-255. DOI: 10.1016/j. jpowsour.2008.09.090.

11. Lu, C.H. \& Lin, Y.K. (2009). Microemulsion preparation and electrochemical characteristics of $\mathrm{LiNi}_{1 / 3} \mathrm{Co}_{1 / 3} \mathrm{Mn}_{1 / 3} \mathrm{O}_{2}$ powders. J. Pow. Sou. 189, 40-44. DOI: 10.1016/j.jpowsour.2008.12.036.

12. Koksbang, R. (1991). Reversibility of the electrochemical lithium insertion in " $\mathrm{Cr}_{3} \mathrm{O}_{8}$ " - comparison with $\mathrm{LiCr}_{3} \mathrm{O}_{8}$. Electrochim. Acta 36, 127-133. DOI: 10.1016/0013-4686(91)85189-E. 13. Vidya, R., Ravindran, P., Kjekshus, A. \& Fjellvåg, H. (2006). Crystal and electronic structures of $\mathrm{Cr}_{3} \mathrm{O}_{8}$ and $\mathrm{LiCr}_{3} \mathrm{O}_{8}$ : Probable cathode materials in Li batteries. Phys. Rev. B. 73, 235113-1-235113-13. DOI: 10.1103/PhysRevB.73.235113.

14. Naoki, K. \& Feng, W. (2010). A Comprehensive Review on Separation Methods and Techniques for Single-Walled Carbon Nanotubes. Materials 3(7), 3818-3844. DOI: 10.3390/ma3073818. 15. Mukherjee, A., Combs, R., Chattopadhyay, J. \& Abmayr, D.W. (2008). Attachment of nitrogen and oxygen centered radicals to single-walled carbon nanotubes salts. Chem. Mater. 20, 7339-7343. DOI: 10.1021/cm8014226. 
16. Chen, Y., Haddon, R.C., Fang, S., Rao, A.M., Eklund, P.C., Lee, W.H., Dicekey, E.C., Grulke, E.A., Pendergrass, J.C., Chavan, A., Haley, B.E. \& Smalley, R.E. (1998). Chemical attachment of organic functional groups to single-walled carbon nanotubes material. J. Mater. Res. 13, 2433-2431. DOI: 10.1557/JMR.1998.0337.

17. Gao, C., He, H., Zhou, L., Zheng, X. \& Zhang, Y. (2009). Scalable Functional Group Engineering of Carbon Nanotubes by Improved One-Step Nitrene Chemistry. Chem. Mater. 21, 360-370. DOI: $10.1021 / \mathrm{cm} 802704 \mathrm{c}$.

18. Han, J. \& Gao, Ch. (2006). Functionalization of carbon nanotubes and other nanocarbons by azide chemistry. Nano-Micro Lett. 2(3), 213-226. DOI: 10.5101/nml.v2i3.p213-226.

19. Dimitrios, T., Tagmatarchis, N., Bianco, A. \& Prato, M. (2006). Chemistry of Carbon Nanotubes. Chem. Rev.106, 1105-1136. DOI: 10.1021/cr050569o.

20. Khabashesku, V. N., Billups, W. E. \& Margrave, J.L. (2002). Fluorination of Single-Wall Carbon Nanotubes and Subsequent Derivatization Reactions. Acc. Chem. Res. 35, 1087-1095. DOI: 10.1021/ar020146y.

21. Viswanathan, G., Chakrapani, N., Yang, H., Wei, B., Chung, H., Cho, K., Ryu, C.Y. \& Ajayan, P.M. (2003). Single-Step in Situ Synthesis of Polymer-Grafted Single-Wall Nanotube Composites. J. Am. Chem. Soc.125, 9258-9259. DOI: 10.1021/ ja0354418.

22. Drabowicz, J., Krasowska, D., Janicka, M., Zajac, A., Wach-Panfiłow, P., Ciesielski, W., Michalski, O., Kulawik, D., Pyzalska, M., Dudzinski, B., Pokora-Sobczak, P., Urbaniak, M. \& Makowski, T. (2016). A stereogenic heteroatom-containing substituent as an inducer of chirality in the derivatives of thiophenes (mono, oligo, and poly), fullerenes C60, and multiwalled nanotubes, Phosp., Sulf. Silic. 191, 211-219. DOI: 10.1080/10426507.2015.1079198.

23. Pyzalska, M., Zdanowska, S., Kulawik, D., Pavlyuk, V., Drabowicz, J. \& Ciesielski, W. (2016). Właściwości fizykochemiczne bromowanych wielościennych nanorurek węglowych funkcjonalizowanych tiofosforanem $O$-metylo- $O-2$-naftylo-L-N-metyloefedryniowym, Przem. Chem. 94/12, 2189-2194. DOI: 10.15199/62.2015.12.20.

24. Bulusheva, L.G., Okotrub, A.V., Flahaut, E., Asanov, I.P., Gevko, P.N., Koroteev, V.O., Fedoseeva, Y.V., Yaya, A. \& Ewels, C.P. (2012). Bromination of Double-Walled Carbon Nanotubes. Chem. Mater. 24, 2708-2715. DOI: 10.1021/cm300630.

25. Souza-Filho, A.G., Endo, M., Muramatsu, H., Hayashi, T., Kim, Y.A., Barros, E.B., Akuzawa, N., Samzonidze, G.G., Saito, R. \& Dresselhaus, M.S. (2006). Resonance Raman scattering studies in Br-2-adsorbed double-wall carbon nanotubes. Phys. Rev. B. 73, 235413-1-235413-12. DOI: 10.1103/ PhysRevB.73.235413.

26. A process for preparing iodinated carbon nanotubes. Application to the Polish Patent Office No. P. 395834.

27. Drabowicz, J., Ciesielski, W. \& Kulawik, D.: Polish patent pending P-409662. 